\title{
Conceptual Model of Expert System-Based Smart Learning: Preliminary Analysis
}

\author{
Sukardi ${ }^{1}$ and Yeka Hendriyani ${ }^{2 *}$ \\ ${ }^{1}$ Department of Electrical Engineering, Universitas Negeri Padang, Padang, Indonesia \\ ${ }^{2}$ Department of Informatics Engineering, Universitas Negeri Padang, Padang, Indonesia, \\ *Corresponding author. Email: yekahendriyani@ft.unp.ac.id
}

\begin{abstract}
Based on the observations, there were still some obstacles faced by students when they want to develop their skills, where students only become passive recipients, so that the motivation of students to learn is reduced. Moreover, in the pandemic today, where learning is carried out by online, it hampers students from mastering learning optimally, because of students cannot interact directly with teachers when facing problems. Because of this pandemic case, one of solutions that can be done in class is the information and communication technology (ICT) using in the learning process, and technology that according to the era of revolution industry (RI) 4.0 development is smart learning based on expert systems. However, in developing smart learning based on this expert system, researchers need to know what is needed both from philosophy, student learning styles and student initial conditions. Researchers also need a paradigm of how they can develop expert system-based smart learning that can be applied effectively in the classroom during the learning process. Therefore, the aim of this study is to conduct an preliminary analysis of expert system-based smart learning, which is in the conceptual model to analyze the theory of education philosophy, learning styles and multiple intelligence that supports the development of expert system-based smart learning, as well as seeing students' initial conditions before smart learning based on expert system was developed. This study uses the method of literature study and the qualitative research using the observation method. Due to the results of this research, it was concluded that philosophically, the theory of constructivism, connectivism, learning styles and multiple intelligence as well as the initial conditions of students also support the development of smart learning based on this expert system.
\end{abstract}

Keywords: constructivism, connectivism, learning styles, expert system, multiple intelligence

\section{INTRODUCTION}

Almost all human life has changed and is read by science and technology. This causes humans to enter an era so that global competition is getting tighter. Humans are faced with complex challenges as well as the tight competitiveness of human resources, and all of this is happening in the current era of RI 4.0. So that this results in the need for human resources who are not only capable of mastering science and technology but also superior human resources (ahmed \& Parson, 2003). Therefore, it is necessary to develop and improve the quality of human resources, which is done by us as a nation. So that education is one of the efforts that can be made to be able to produce quality human resources, able to compete and excel (Ai, 2017). In Government Regulation No. 32 of 2013, regarding the learning process in vocational education, there is one solution that can be applied in the learning process. Where the vocational education provides opportunities for students to be able to develop their skills and creativity towards these abilities, so that they have skills that are in accordance with their fields.

However, based on the observations that have been made, there are still some obstacles faced by students when they want to develop their skills, where students only as a passive recipient, so that students' motivation to learn is reduced. Especially in the current pandemic, where learning is carried out by online, it makes students obstructed to master the material optimally, because of students cannot interact teachers directly when they are facing problems. This observation also explains that students need an innovative learning and teaching model that can facilitate students to learn independently, even when they face the problems, students can solve them with the facilities of the learning model.

In fact, as stipulated that the National Higher Education Standards in the Government Regulation no. 32 of 2013 in Article 19 (1). In this article, the fact is that the learning process occurs there is no one-way communication, where the teacher provides an 
explanation and the students only listen. However, in learning there must be interactive two-way communication between teachers and students. So, the existence of a learning model in education is something that grows in this article, since learning without the relevant learning model support, education will not run effectively. The learning model is needed to enable conducive learning by placing students as the center of learning and the teacher as facilitators in an effort to enrich the students' learning experience. Learning experiences are obtained through students' direct involvement in a series of activities to explore the environment and interaction with subject matter. Furthermore, students construct their own knowledge based on the learning experiences they have obtained.

In the learning process, there are several types of models used, by the implementation of a good learning model which includes teaching, assignments, question and answer, writing, reading, presentation and evaluation depending on one or more three basic model of dialogue as follows (Boettcher, 1999): a). Dialogue between lecturers and students, b). Dialogue between students and learning resources, c). Dialogue between students. According to education experts, if these three aspects are carried out in a balanced manner, the achievement of learning objectives can be done successfully (Hasbullah, 2007). One of solutions that can be done in the class is the ICT using in the learning process. One of the technologies that developed in the 4.0 industrial revolution era is smart learning based on expert systems.

Expert system-based smart learning is a learning model that utilizes expert system technology in its implementation. When implementing a learning model in the learning process, the teacher can use one of the branches of the artificial intelligence system, namely the expert system. An expert system is a technology, where the system adopts human science and is applied to the computer, so that computers have the ability to solve problems as is done by an expert (Wulansari et al., 2019).

In a learning process, of course there will be a lot of things that must be learned by students so that students can understand the learning optimally. Although no matter how much material, as well as the problems faced and confusing students, this expert system-based smart learning model is useful to help in the problems classification remembering in learning material so that it can recognize its characteristics and can minimize errors to understand it. The Expert System-based smart learning has the advantage of facilitating practical problems faced by students in learning when the expert or teacher is absent (Paiva et al, 2017).

Another advantage of the Expert System-based smart learning can help students that have well competencies, in addition to trait the student to learn independently. Students are determinants of learning for themselves and not just objects that receive passively. Expert systems that are always associated with enjoyable and creative learning conditions are expected to provide high motivation to students in the learning process (Pavlekovic, 2009). Students can participate actively in learning with an expert system, because an expert system can make students learn quickly, independently, and can master learning material optimally (Hung et al, 2015).

Based on the background described above, this study needs to be done as a preliminary analysis in developing expert system-based smart learning. Before developing expert system-based smart learning, researchers need to know what things are needed from the philosophy, student learning styles and students' initial conditions. Researchers also need a paradigm of how they can develop expert system-based smart learning that effectively implemented in the learning process (Al Fatta, 2007). Therefore, this study aims at conducting an preliminary analysis of expert systembased smart learning, which is a conceptual model to analyze the theory of education philosophy, learning styles and multiple intelligence that supports the development of expert system-based smart learning, as well as seeing students' initial conditions before expert system-based smart learning was developed.

\section{METHOD}

This study used literature study method and qualitative research type using observation method. Literature study was carried out by reviewing as many journals over the past 15 years related to learning theory, learning styles and multiple intelligence then linked to expert system-based smart learning to be developed.

Based on literature data in previous studies, a systematic review was carried out which included two steps, namely as follows: first, reviewing journals that have been found in the e-database. Second, screening to the journals related to learning theory, learning styles and multiple intelligence accordance to the expert systembased smart learning will be developed. Meanwhile, observations were made to obtain information about students' initial conditions before the expert systembased smart learning model was developed. Observations were conducted by structured interviews with students and lecturers in the Department of Electrical Engineering Education, Padang State University.

\section{RESULTS AND DISCUSSIONS}

This research is a preliminary study of the expert system-based smart learning development. This preliminary study aims at conducing an initial analysis of expert system-based smart learning, which is a conceptual model to analyze the theory of education 
philosophy, learning styles and multiple intelligence that supports the development of expert system-based smart learning, as well as seeing students' initial conditions before expert system-based smart learning developed. Philosophically, the theories that supports the development of expert system-based smart learning are as follows:

\section{a. Constructivism}

Constructivism learning theory in the view of higher education is divided into two types of learning, namely individual constructivism and social constructivism. In this individual constructivism, students are given the opportunity to build their own knowledge through cognitive processes, so that they can gain knowledge from experience, not by memorizing facts obtained from other people. While social constructivism is where students are given the opportunity to build knowledge through the interactions they get between knowledge and social or cultural situations in the context of learning (Ormrod, 2006); (Woolfolk, 2010: 311).

Constructivist learning theory views learning as more than just remembering. Students who understand and are able to apply the knowledge they have learned, are able to solve problems, find something for themselves, and struggle with various ideas. The point of constructivism theory is that students have to discover and turn the information into themselves and be able to construct their own knowledge through interaction with their environment (Rifai, 2009).

One of the constructivism theory figures is Vygotsky. He emphasized the importance of social aspects in learning. Vygotsky, (2019) believes that cognitive abilities come from social and cultural relationships. Where social interaction by other people can spur the construction of new ideas and increase the intellectual development of students. The principle of constructivism states that learning is a process of interaction between what we already know and what we will learn, interactions between people and mental interactions. Each individual has initial knowledge and understanding of something that can be used again in new situations. This principle also explains that learning is a context-specific process, meaning that all learning always has a specific interaction context. The principle of learning is a metacognitive process.

Metacognitive is the idea where individuals are aware of mental or cognitive processes and how learners learn (Sakti et al, 2020). This theory supports the development of expert system-based smart learning because expert system-based smart learning is a learning model that can help students construct knowledge based on their initial knowledge. This expert system-based smart learning also fulfills four learning assumptions in constructivism theory, namely physical knowledge is constructed by students who are involved in active learning, knowledge is symbolically constructed by students who make representations of their own activities, social knowledge is constructed by students. which conveys its meaning to others and theoretical knowledge is developed by students who manage to describe objects they not understand.

\section{b. Connectivism}

George Siemen was the first one who publish the term of connectivism theory on 2004. It is defined as a learning theory that integrates the foundations investigated by theories of clutter, networking, complexity, and self-organizing. Learning in the sense of Connectivism is understood as a process that occurs in an environment of changes in the core elements of learning that are blurred and not fully under the control of an individual. In connectivism, learning is defined as: Activities starting from knowing activities to creating actionable knowledge. These activities can occur outside of humans (in an organization, a database, and so on). This activity focuses on relating specific collections of information, and other relationships that allow us to learn more. Therefore, the ability to make these connections is more important than the knowledge we have mastered. Connectivism is based on an understanding of the fact that decision-making in the information age will be based on rapidly changing foundations. New information will be obtained on an ongoing basis. It is very important for someone to have the ability to distinguish between important and insignificant information. Apart from that, it is also very important for someone to be able to create new information whenever new information can be used as a basis for decision making.

Connectivism theory offers a new model in the 21 st century of the education system to get out of behind, of course for wise people, without having to abandon existing educational and teaching theories, which should continue to be developed and refined, such as the theory of behaviorism, cognitivism, constructivism, and others (Sakti \& Sukardi, 2020). It can be done quickly because the existing technological facilities make it possible to connect between educational components. In addition, sources of knowledge and information on campus, experts, lecturers do not have to be directly accessed by students in one common room but can be by remote conferencing via a computer equipped with sophisticated programs or software (interactive communication) even through PDAs and cellphones for discussion. In addition, students can also directly access (connect) with the materials needed in cyberspace. In cyberspace, there are approximately 120 million websites and there are 
approximately 11 million scientific articles as well as tens of millions of data and other information that can be accessed anytime anywhere (Ryan \& Tylburi, 2013).

Based on the description above, it is clear that this theory supports the use of technology in learning. Connectivism theory that was born from the development of information and communication technology bridges (connects) between components in education (such as: lecturers, universities, and students) as well as between the components of education with information and communication technology. Therefore, this theory supports the development of expert system-based smart learning in terms of the use of technology in learning, and also becomes a connection between educators and students.

\section{c. Learning Style}

Learning styles and preferences take many forms, and not everyone fits to one category. However, in general, the most common types of learners are as follows:

1) A visual learner is someone with a alternative that prefers to look at and observe things, consists of pictures, diagrams, written instructions and etc. It is called the "spatial" learning style, where students can understand information well through seeing the information presented visually. It is your student scribbling, list maker, and your student taking notes. A blackboard or smart board is the educator's best friend when they teach this type of student. Students are given the opportunity to draw diagrams on the board, the teacher can also ask students to make examples based on topics that students have discussed. Students who learn in a spatial style, the teacher should produce leaflets and use presentations regularly. This is because students with a spatial style need a lot to understand the material. So, the teacher must give time and space to students in absorbing the material.

2) Students who tend to better understand material when learning is amplified by sound is the definition for auditory learners. Students with this auditory learning style prefer lectures to reading notes, and to reinforce their new concepts and ideas, they often use their own voices by reading a passage aloud. They are good at explaining things verbally and are not afraid to appear in front of the class. They also often repeat what the teacher says to them and tend to be slow at reading. Students with this auditory style cannot remain silent for long periods of time, the teacher must ask them to repeat the new concept again, asking questions and letting them answer. The group discussion method is one way that teachers can teach students with auditory and verbal styles so that they can understand the material well. Apart from group discussions, presenting videos and music are also good methods for students with auditory and verbal learning styles.

3) Students with this kinesthetic learning style are students who learn through experience or do something, so they are called tactile learners. In order to understand the material easily, students with this kinesthetic learning style like to play shows or do work using their hands. Students with this learning style also cannot stay still for long periods of time and they excel at sports or the arts (dancing), they need lots of rest when studying. The teacher who teaches these kinesthetic students is to invite them to move. The teacher can instruct students to act out certain scenes from the lessons being taught. The teacher can also encourage students to include movements in learning, such as moving to help them memorize, playing games in class or asking students to write on the blackboard.

Based on this learning style theory, students can improve their understanding of learning styles through the learning process using asynchronous online, synchronous or offline communication, depending on mobile equipment and the reliability of the internet. It supports the development of expert system-based smart learning, because passive learning is no better than active learning, where students can remember, enjoy and be implemented. Active learning methods can develop students' thinking so that they can improve the conceptualization of what they make. This creates neural connections in the brain during the active learning process. This process is called learning. Whereas passive learning is like a person who cannot make neural connections, or the conceptualization of active learning involves students in learning activities, with prioritized skills, and expert system-based smart learning also provides active learning for students.

\section{d. Multiple Intelligence}

There are nine Multiple Intelligence popularized by Gardner, namely as follows: 1) students who have good development of verbal skills and are sensitive to the meaning, rhythm of words and sounds are called verbal-linguistic intelligence; 2) students are able to think abstractly and conceptually, and students are able to distinguish numerical and logical patterns called mathematical logical intelligence; 3) students who are able to think through pictures, and have abstract and accurate visualizations are called spatial-visual intelligence; 4) students who are able to control their body movements and can handle an object deftly are called body-kinesthetic intelligence; 5) students who are able to produce tones and rhythms are called musical intelligence; 6) students who are able to respond to and detect other people's motivation, desires and moods appropriately are called interpersonal intelligence; 7) 
students who have the ability to be self-aware and in tune with values, thoughts, beliefs and feelings are called interpersonal intelligence; 8) students who are able to categorize and recognize animals, plants and other natural objects are called naturalist intelligence; 9) students who are sensitive and able to answer deep questions about human existence are called existential intelligence (Gardner, 2003).

A person's preference for learning is related to human potential, so Gardner focuses on a person's potential, which is the fact that someone has a unique mix of abilities and intelligence/skills. This model can be utilized for understanding "personality, preferences, and overall strengths". Gardner claims that someone who has an interesting in one intelligence do so in conjunction with others when "they develop skills and solve problems" (Campbell et al., 2002).

People belong to different strengths and intelligence. Example, someone who are "interviewed" as a means of gaining access to courses may be incorrectly labeled as undesirable because of improper assessment (bad interview questions, bias against perceptions of "perfect students," and criteria). "In life, we need people who are collectively good at various things. A balanced world, and a balanced organization and team, naturally consists of people who have a different mix of intelligences. It gives the group a fuller collective capacity than a group of identical specialists. "

When developing curricula, selecting subject activities, learning strategies and planning lessons, teachers can use Gardner's multiple intelligence theory. Where the teacher can design lessons that can help students develop the strengths they have, so that it can trigger their self-confidence and they can develop areas that are not mastered. Various kinds of student learning preferences that are important to pay attention to are methods, assessments, and meaningful activities.

Based on the theory of multiple intelligence, expert systems-based smart learning was developed. It is because the expert system-based smart learning can be used by students who have a variety of intelligences, the innovations contained in this expert system-based smart learning can be used for various kinds of skills possessed by students, and so it is not monotonous and can make students motivated to learn.

The initial condition of the students explained that the age of the students was in the range of 17 years to 20 years where students were entering the transition stage from adolescence to adulthood. According to Piaget's theory in Trianto (2010: 71), the cognitive development of these students at the formal operational growth stage. Students should ideally have their own mindset in this period, they are trying to solve abstract and complex problems, so that they can imagine various alternative solutions that they can use in solving these problems, and they can think about the possible outcomes and consequences of these solutions. Students will process information and adapt it to their thinking at this stage, they are no longer recipients of information. Students are able to think logically and abstractly at this operational stage. However, each student's abstract thinking ability is not the same. Solutions contained in expert system-based smart learning can help students to face problems in learning and make them easier for students to understand.

At this age, students are characterized by a tendency to like music with soft harmony and rhythm, and inconspicuous contrasting colors. Besides that, they also enjoy interesting animated characters or images. Combining the components of color, music, and student creativity in learning in a fun way can foster student motivation in the learning process. This component can encourage students' right brain which can help students in the learning process and store messages for a long time, since the memory of the right brain is long. This is in accordance to the opinion of Shah (2010: 33) which states that someone able to think abstractly at the formal operational stage.

\section{CONCLUSION}

Constructivism theory supports the development of expert system-based smart learning because expert system-based smart learning is a learning model that can help students construct knowledge based on their initial knowledge. The expert system-based smart learning also fulfills the four learning assumptions in constructivism theory, which is called physical knowledge which is developed by students who are actively involved in learning. In order to represent their own activities, students build knowledge symbolically and socially. Then convey the meaning of the learning they have constructed to others. Students also try to describe objects they do not fully understand. Connectivism theory that was born from the development of information and communication technology bridges (connects) between components in education (such as: lecturers, universities, and students) as well as between the components of education with information and communication technology. It causes the theory to support the development of expert system-based smart learning in terms of the use of technology in learning, and also to connect between educators and students. In terms of learning styles that support the development of expert system-based smart learning because expert systembased smart learning also provides active learning for students. Finally, based on the theory of multiple intelligence, smart learning based on expert systems was developed. It is because the expert system-based smart 
learning can be used by students who have a variety of intelligences, the innovations contained in this expert system-based smart learning can be used for various kinds of skills possessed by students, and so it is not monotonous and can make students motivated to learn. The condition of early students also supports the development of expert system-based smart learning because in the transition period of adolescence to adulthood, ideally students have their own mindset to solve the problems they face, both abstract and complex problems, they can also imagine various alternative solutions to solve problems, as well as the possible consequences of the solutions they use.

\section{REFERENCES}

[1] Ahmed, S. and Parsons, D., "Abductive science inquiry using mobile devices in the classroom," Comput. Educ., vol. 63, pp. 62-72, 2013.

[2] Ai, H., "Providing graduated corrective feedback in an intelligent computer-assisted language learning environment," ReCALL, vol. 29, no. 3, pp. 313-334, 2017.

[3] Al Fatta, H., Analisis dan Perancangan Sistem Informasi. Yogyakarta: Andi Offset, 2007.

[4] Boettcher, J. and Conrad, R., 1999. Faculty Guide for Moving Teaching and Learning to the Web, League for Innovation in the Community College

[5] Campbell, Linda., Campbell, Bruce., Dickinson, Dee., et al. 2002. Melesatkan kecerdasan. (Terjemahan Tim Inisiasi). Jakarta Inisiasi Press.

[6] Gardner, Howard. 2003. Multipke Intelligences: Kecerdasan Majemuk Teori dan Praktek. Penerjemah Alexander Sindoro. Batam: Interaksara.

[7] George Siemens. 2004. Connectivism: A Learning Theory for the Digital Age.

[8] Hasbullah. 2007. Perancangan dan Implementasi Model Pembelajaran E-learning untuk Meningkatkan Kualitas Pembelajaran di JPTE FPTK UPI. Bandung: Jurusan Pendidikan Teknik Elektro FPTK UPI.

[9] Hung, Y. H., Lin, C. F., and Chang, R. I., "Developing a dynamic inference expert system to support individual learning at work," Br. J. Educ.
Technol., vol. 46, no. 6, pp. 1378-1391, 2015.

[10] Ormrod, J. (2006). Educational psychology: Developing learners. In Educational psychology: Developing learners (New Jersey). Pearson Education inc.

[11] Paiva, R. C., Ferreira, M. S., and Frade, M. M., "Intelligent tutorial system based on personalized system of instruction to teach or remind mathematical concepts," J. Comput. Assist. Learn., vol. 33, no. 4, pp. 370-381, 2017.

[12] Pavlekovic, M., Zekic-Susac, M., and Djurdjevic, I., "Comparison of intelligent systems in detecting a child's mathematical gift," Comput. Educ., vol. 53, no. 1, pp. 142-154, 2009.

[13]Ryan, A., \& Tilbury, D. (2013). Flexible Pedagogies: new pedagogical ideas. November, 41. http://www.heacademy.ac.uk/resources/detail/flexi ble-

learning/flexiblepedagogies/new_ped_ideas/report ?utm_medium=email\&utm_source $=$ The + Higher+ Education+Academy\&utm_campaign=4074096_1 40506\&utm_content=New-pedagogical-ideasreport

[14] $\overline{\text { Sakti, }}$ R. S. \& Sukardi. (2020). Petualangan Bersama CBI (Computer Based Instruction)Flipped Classroom Pada Mata Pelajaran Jaringan Komputer: Efek Empiris. Journal of Information Technology and Computer Science. 3 (2), pp. 95 101.

[15] Sakti, R. S., Sukardi, Giatman, M., Nazar, E., Wakhinuddin \& Waskito. (2020). Flipped Classroom-Computer Based Instruction untuk Pembelajaran Revolusi Industri 4.0: Rancang Bangun dan Analisis Kebutuhan. Edumatic: Jurnal Pendidikan Informatika. 4 (1), pp. 63-72.

[16] Vygotsky, L. S. (2019). Interaction between Learning and Development. In Mind in Society (pp. 79-91). https://doi.org/10.2307/j.ctvjf9vz4.11

[17] Woolfolk, A. (2004). Educational Psychology. Allyn \& Bacon.

[18] Wulansari, R. E., Puyada, D., Wijaya, I., and Rukun, K., "Effectiveness Of Instructional Media Based Game On Mathematics At Vocational High School," Int. J. Res. Sci. Manag., vol. 4, no. 12, pp. 125-128, 2017. 